\title{
HUBUNGAN POLA MAKAN DAN AKTIVITAS FISIK TERHADAP TEKANAN DARAH PADA PASIEN HIPERTENSI DI KAPUAS HULU
}

\author{
Muhammad Firdaus* ${ }^{\star}$ Windu CHN Suryaningrat* ${ }^{\star 凶}$
}

\begin{abstract}
Abstrak
Hipertensi merupakan penyebab utama morbiditas dan mortalitas di Indonesia. Komplikasi hipertensi menyebabkan sekitar 9,4 kematian di seluruh dunia setiap tahunnya. Kabupaten Kapuas Hulu memiliki prevalensi hipertensi sebesar $36 \%$, angka tersebut lebih tinggi dari angka prevalensi hipertensi nasional. Penelitian ini bertujuan untuk mengetahui adanya hubungan aktivitas fisik dan pola makan dengan tekanan darah pada pasien hipertensi di wilayah Kecamatan Semitau dan Suhaid, Kabupaten Kapuas Hulu. Penelitian ini merupakan observasional analitik dengan desain penelitian potong lintang (cross-sectional) yang dilaksanakan pada bulan Maret hingga Desember 2019. Data penelitian diperoleh dengan menggunakan kuesioner penelitian. Penelitian ini berhasil mengumpulkan 100 pasien hipertensi yang bersedia menjadi subjek penelitian dengan rerata (SD) usia 56 (9) tahun dan didominasi laki-laki (71\%), dan 10\% dengan pasien hipertensi terkontrol. Penelitian ini menunjukkan bahwa aktivitas fisik memiliki hubungan yang bermakna dengan tekanan darah pada pasien dengan hipertensi $(p=0,027)$; dengan rerata (SD) nilai MET pasien hipertensi terkontrol dan tidak terkontrol sebesar 5660,0 $(4229,4)$ menit/minggu dan 5077,8 $(8952,4)$ menit/ minggu. Di sisi lain, pola makan tidak menunjukkan hubungan yang bermakna terhadap tekanan darah pada pasien hipertensi $(p=1,000)$. Berdasarkan studi ini, dapat disimpulkan bahwa peningkatan aktivitas fisik mempengaruhi pengontrolan tekanan darah pada penderita hipertensi.
\end{abstract}

Kata kunci: aktivitas fisik, hipertensi, pola makan, tekanan darah.

\section{ASSOCIATION BETWEEN DIETARY INTAKE AND PHYSICAL ACTIVITY WITH BLOOD PRESSURE IN HYPERTENSION PATIENTS IN KAPUAS HULU DISTRICT}

\begin{abstract}
Hypertension is number one causing morbidity and mortality worldwide. Its complications caused 9.4 death worldwide, annually. The prevalence of hypertension in Kapuas Hulu district showed 36\%, higher from the national prevalence of hypertension. This study aimed to know the association between dietary intake and physical activity with blood pressure control in hypertension patient in Semitau and Suhaid area, Kapuas Hulu district, which was conducted from March to November, 2019. This analytic observational study used a cross -sectional research design. Data were collected using a self-made questionnaire. This study collected 100 hypertension patients. The subjects of this study were $71 \%$ men with mean (SD) age was 56 (9) years, and $10 \%$ with controlled hypertension. This study found that physical activity significantly associate with blood pressure control in hypertension patients ( $p=0.027$ ); mean (SD) total MET in controlled and uncontrolled hypertension were $5660.0(4229.4) \mathrm{min} /$ week and $5077.8(8952,4) \mathrm{min} /$ week, respectively. However, dietary intake did not significantly associated with blood pressure control in hypertension patients $(p=1.000)$. In conclusion, there were association between physical activity and blood pressure control, but there was no association between dietary intake and blood pressure control in hypertension patient.
\end{abstract}

Keywords: blood pressure, dietary intake, hypertension, physical activity.

*RSUD Semitau, Kabupaten Kapuas Hulu, Kalimantan Barat

E-mail: winduchan@gmail.com 


\section{Pendahuluan}

Hipertensi merupakan penyebab utama morbiditas dan mortalitas di Indonesia. Komplikasi hipertensi menyebabkan sekitar 9,4 kematian di seluruh dunia setiap tahunnya. Hipertensi menyebabkan setidaknya $45 \%$ kematian karena penyakit jantung dan $51 \%$ kematian karena stroke. Kematian yang disebabkan oleh penyakitkardiovaskuler, terutama penyakit jantung koroner dan stroke diperkirakan akan terus meningkat mencapai 23,3 juta kematian pada tahun 2030.1

Hipertensi didefinisikan sebagai peningkatan tekanan darah sistolik $\geq 140$ dan/atau diastolik $\geq 90 .^{2}$ Menurut data WHO, satu dari empat pria dan satu dari lima wanita di seluruh dunia terkena hipertensi, pada tahun 2025 angka kejadian hipertensi diseluruh dunia diperkirakan mencapai $29,2 \%$ dari populasi dunia. ${ }^{3}$ Dari 972 juta penderita hipertensi, 333 juta berada di negara maju dan 639 juta sisanya berada di negara berkembang, termasuk Indonesia. ${ }^{4}$ Prevalensi hipertensi di Indonesia berdasar Riset Kesehatan Dasar (Riskesdas) tahun 2018 sebesar 34,1\%, persentase ini mengalami kenaikan dari tahun 2013 yaitu 25,8\%. Prevalensi hipertensi untuk wilayah Kalimantan Barat tahun 2018 mencapai $36,99 \%$. Prevalensi hipertensi di Kabupaten Kapuas Hulu sebesar 36\%, di bawah persentase provinsi tetapi di atas prevalensi nasional. 5

Berbagai faktor risiko telah dihubungkan dengan hipertensi, antara lain umur, riwayat keluarga dengan hipertensi, jenis kelamin, pendidikan, obesitas, kurangnya aktivitas fisik, pola makan yang tidak sehat, merokok, konsumsi alkohol, stres mental, dan konsumsi kafein. ${ }^{6}$ Faktor risiko tertinggi penyakit tidak menular menurut data dari Riskesdas tahun 2013 adalah konsumsi kurang makan sayur dan buah $(93,5 \%)$, merokok (36,3\%), obesitas sentral $(26,6 \%)$, dan kurangnya aktivitas fisik $(26,1 \%)$

Pola makan merupakan salah satu faktor risiko utama yang dapat dimodifikasi dalam penyakit hipertensi. Pola makan yang tinggi akan daging merah dan olahan, makanan cepat saji, makanan berlemak dan makanan penutup yang manis (dessert) dapat menyebabkan peningkatan tekanan darah, namun pola diet kaya akan sayuran, biji-bijian utuh, buah-buahan, daging tanpa lemak, ikan dan produk susu rendah lemak terbukti berhubungan dengan penurunan tekanan darah. ${ }^{7,8}$ Faktor risiko lain adalah aktivitas fisik. Aktivitas fisik diketahui yang mampu menurunkan risiko hipertensi melalui mekanisme penurunan resistensi pembuluh darah dan penekanan aktivitas sistem saraf simpatik dan sistem renin-angiotensin. ${ }^{9}$ Aktivitas aerobik selama 30-45 menit/hari terbukti efektif mengurangi risiko hipertensi sebesar $19-30 \% .10$ Orang-orang yang tidak aktif cenderung mempunyai detak jantung lebih tinggi. Semakin tinggi detak jantung semakin keras jantung bekerja untuk setiap kontraksi dan semakin kuat desakan pada dinding arteri. ${ }^{11}$ Pemerintah melalui Kementrian Kesehatan saat ini melaksanakan beberapa program di antaranya: sosialisasi Gerakan Masyarakat Hidup Sehat (GERMAS) dan menerapan pola hidup sehat dengan perilaku CERDIK (Cek kesehatan berkala, Enyahkan asap rokok, Rajin aktivitas fisik, Diet sehat dan seimbang, Kelola stres), sebagai upaya untuk menurunkan angka kejadian hipertensi di Indonesia.

Berbagai faktor risiko tersebut seringkali dikaitkan dengan angka kejadian hipertensi, tetapi belum banyak penelitian yang mengevaluasi pengontrolan tekanan darah pada pasien yang telah mengalami hipertensi. Penelitian ini bertujuan untuk mengetahui hubungan pola makan dan aktivitas fisik terhadap kontrol tekanana darah pada pasien hipertensi di daerah Semitau dan Suhaid, Kapuas Hulu, Kalimantan Barat. Pemilihan Kabupaten Kapuas Hulu sebagai lokasi penelitian karena masih sedikit penelitian mengenai hipertensi di daerah tersebut, serta faktor lokasi sebagai tempat tinggal peneliti sehingga mendukung untuk dilakukan penelitian di Kabupaten Kapuas Hulu. 


\section{Bahan dan Metode}

Penelitian ini merupakan observasional analitik dengan desain penelitian potong lintang (cross-sectional). Penelitian dilaksanakan di ruang lingkup kerja Kecamatan Semitau dan Suhaid, Kabupaten Kapuas Hulu, Provinsi Kalimantan Barat dari bulan Maret 2019 hingga Desember 2019. Pelaksanaan penelitian telah mendapatkan ijin dari Rumah Sakit Umum Daerah Semitau (Nomor: 445/85/RSUDS_UK/2019) dan Puskesmas Suhaid (812/220/ SK/PUSK.SHD/SET-C) sebagai institusi yang berwenang di daerah tersebut. Subjek penelitian berjumlah 100 orang dikumpulkan dengan teknik simple random sampling. Kriteria inklusi penelitian ini adalah pasien dengan diagnosis tekanan darah tinggi sebelum atau saat pengambilan data dilakukan dan bersedia mengisi kuesioner yang disediakan. Data kuesioner yang tidak lengkap menjadi kriteria eksklusi penelitian ini. Sebelum pengisian kuesioner, responden ditanyakan kesediaannya dan diwajibkan menandatangani lembar informed consent sebagai bukti kesediaan mengikuti penelitian.

Data karakteristik subjek, tekanan darah, aktivitas fisik, dan pola makan diperoleh dengan menggunakan kuesioner dan pemeriksaan fisik. Data karakteristik subjek disajikan dalam tabel; variabel kategorik disajikan dalam frekuensi dan persentase dan variabel numerik disajikan dalam rerata (standar deviasi/SD) atau median (nilai minimum dan maksimum), sesuai distribusi datanya. Karakteristik subjek mencantumkan usia, jenis kelamin, pendidikan, pekerjaan, riwayat penyakit, indeks Brinkman, indeks massa tubuh, tekanan darah, kadar gula darah sewaktu (GDS), kadar kolesterol, dan kadar asam urat. Indeks massa tubuh diperoleh dengan perhitungan rumus berat badan $(\mathrm{kg})$ dibagi tinggi badan $(\mathrm{m})$ kuadrat. Pengukuran berat badan dan tinggi badan menggunakan timbangan yang terkalibrasi dan meteran. Data tekanan darah diperoleh dengan melakukan pemeriksaan tekanan darah di lengan kanan/ kiri dalam posisi duduk. Nilai tekanan darah dikelompokkan dalam grup terkontrol (TD $\leq$ 140/90) dan tidak terkontrol (TD > 140/90). Data GDS, kolesterol, dan asam urat diperoleh

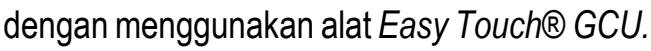
Data pola makan diperoleh menggunakan kuesioner yang telah digunakan oleh Romauli dengan nilai reliabilitas baik (Cronbach's alpha 0,862 ) yang terdiri atas 8 pertanyaan dengan skor maksimal 16 poin. ${ }^{12}$ Skor $>12$ poin termasuk dalam kategori pola makan baik, sedangan $\leq 12$ poin termasuk dalam kategori tidak baik. Data pola aktivitas fisik diukur dengan menggunakan instrumen Global Physical Activity Questionnaire (GPAQ) dengan tingkat validitas sedang dan reliabilitas baik. Variabel aktivitas fisik akan disajikan dalam median (minimum-maksimum) untuk nilai metabolic equivalent (MET) total dalam menit tiap minggu.

Analisis data secara univariat dan bivariat dilakukan menggunakan IBM SPSS Statistic ver. 26. Analisis univariat dilakukan untuk variabel-variabel dalam karakteristik subjek. Analisis bivariat yang digunakan untuk menilai variabel tekanan darah dan pola makan adalah uji Fisher's. Variabel tekanan darah dan pola aktivitas fisik dianalisis dengan uji nonparametrik Mann Whitney U. Hubungan statistik yang bermakna dinyatakan bila diperoleh nilai $p \leq 0,05$ dari masing-masing analisis bivariat tersebut.

\section{Hasil}

Penelitian ini berhasil mengumpulkan 100 pasien hipertensi yang bersedia menjadi subjek penelitian dengan rerata $\pm S D$ usia $56 \pm 9$ tahun dan didominasi laki-laki (71\%). Pasien hipertensi yang memiliki tekanan darah terkontrol terdata sebanyak 10 orang (10\%) dan 6 $(60 \%)$ orangnya berjenis kelamin laki-laki. Pasien hipertensi yang tidak sekolah dan hanya mengenyam pendidikan sekolah dasar (SD) masih menjadi kelompok mayoritas (65\%) di daerah Semitau dan Suhaid. 
Komplikasi hipertensi yang ditemui, antara lain stroke $(6 \%)$ dan gagal jantung (2\%). Penyakit penyerta yang memperberat kondisi pasien hipertensi yang terdata, yaitu diabetes melitus $(11 \%)$ dan obesitas (58\%). Data karakteristik subjek penelitian tercantum dalam Tabel 1.

Pengolahan data untuk variabel pola makan dengan tekanan darah dilakukan dengan uji Fisher's, karena syarat penggunaan uji Chi-square tidak terpenuhi. Berdasarkan uji tersebut, didapatkan nilai $p=$ 1,000. Hasil tersebut menunjukkan adanya perbedaan proporsi yang tidak bermakna antara pola makan dengan pengontrolan tekanan darah pada pasien hipertensi. Berbeda dengan hasil analisis variabel aktivitas fisik dengan tekanan darah menggunakan uji
Mann Whitney, sebagai uji alternatif dari uji T tidak berpasangan dari data yang tidak terdistribusi normal. Aktivitas fisik total tiap minggu yang ditampilkan dalam nilai MET menunjukkan adanya perbedaan rerata yang bermakna dengan tekanan darah pada pasien hipertensi ( $p=0,027$ ). Ketika dihubungkan masingmasing jenis aktivitas fisik tiap minggunya dengan tekanan darah, didapatkan hanya aktivitas fisik kerja yang memiliki hubungan bermakna $(p=0,015)$ dengan tekanan darah, sedangkan jenis aktivitas fisik saat transfer dan rekreasi tidak menunjukkan perbedaan rerata yang signifikan $(p=0,336$ dan $p=$ 0,095). Tabel 2. menunjukkan hasil analisis pola makan dan aktivitas fisik terhadap tekanan darah pada pasien hipertensi.

Tabel 1. Karakteristik subjek penelitian

\begin{tabular}{lc}
\hline \multicolumn{1}{c}{ Variabel } & $\begin{array}{c}\text { Frekuensi }(\mathrm{N}=100) \\
\mathrm{n}(\%)\end{array}$ \\
\hline Usia (tahun), mean (SD) & $56,0(9,0)$ \\
Jenis kelamin & \\
Laki-Laki & $71(71,0)$ \\
Perempuan & $29(29,0)$ \\
Pendidikan & \\
Tidak sekolah & $22(22,0)$ \\
SD & $43(43,0)$ \\
SMP & $18(18,0)$ \\
SMA & $13(13,0)$ \\
Diploma/Sarjana & $4(4,0)$ \\
Pekerjaan & \\
Karyawan/Pedagang/Guru & $17(17,0)$ \\
Petani/Buruh/Nelayan/Tentara & $30(30,0)$ \\
Pensiunan/lbu Rumah Tangga & $53(53,0)$ \\
Penyakit penyerta & \\
DM tipe 2 & $11(11,0)$ \\
Gagal Jantung & $2(2,0)$ \\
Stroke & $6(6,0)$ \\
\hline
\end{tabular}


Lanjutan Tabel 1. Karakteristik subjek penelitian

\begin{tabular}{lc}
\hline \multicolumn{1}{c}{ Variabel } & Frekuensi $(\mathrm{N}=100)$ \\
$\mathrm{n}(\%)$
\end{tabular}

Keterangan: $\mathrm{SD}=$ sekolah dasar; $\mathrm{SMP}=$ sekolah menengah pertama; $\mathrm{SMA}=$ sekolah menengah atas; $\mathrm{DM}=$ diabetes mellitus; IMT=indeks masa tubuh; GDS=gula darah sewaktu.

Tabel 2. Hubungan pola makan dan aktivitas fisik terhadap tekanan darah pada pasien hipertensi Kecamatan Semitau dan Suhaid periode Maret-November 2019

\begin{tabular}{llccc}
\hline & & \multicolumn{2}{c}{ Tekanan Darah } & \\
\cline { 3 - 4 } & & Terkontrol & Tidak & \\
\hline Pola makan (\%) & Baik & 2 & 19 & $1,000^{*}$ \\
& Tidak & 8 & 71 & \\
Aktivitas fisik, mean(SD) & Total & $5660,0 \pm 4229,4$ & $5077.8 \pm 8952,4$ & $0,027^{+}$ \\
& Kerja & $4944,0 \pm 3446,9$ & $4209,6 \pm 8219,6$ & $0,015^{+}$ \\
& Transfer & $356,0 \pm 393,5$ & $737,1 \pm 1334,1$ & $0,336^{+}$ \\
& Rekreasi & $360,0 \pm 1001,5$ & $131,1 \pm 613,1$ & $0,095^{+}$ \\
\hline
\end{tabular}

Keterangan: *Uji Fisher; ${ }^{\dagger} U j i$ Mann Whitney; p bermakna $\leq 0,05$. 


\section{Pembahasan}

Subjek penelitian ini didapatkan $71 \%$ pria dan $29 \%$ wanita menderita hipertensi dengan rerata usia adalah 56 tahun. Hal ini sejalan dengan penelitian dari Choi $\mathrm{HM}$ et al. yaitu prevalensi hipertensi pada pria lebih besar dari pada wanita dengan persentase masingmasing sebesar $34,6 \%$ dan 30,8\%.16 Hasil penelitian ini juga sesuai dengan data CDC tahun 2017 yang menyatakan bahwa proporsi terbesar penderita hipertensi adalah pasien dengan usia di atas 40 tahun. Prevalensi hipertensi CDC 2017 untuk usia 40-59 tahun sebanyak $33,2 \%$ dan untuk usia di atas 60 tahun sebanyak $63,1 \% .{ }^{15}$ Jenis kelamin juga memiliki pengaruh pada terjadinya hipertensi, pada usia muda di bawah 60 tahun, pria lebih banyak yang menderita hipertensi dibandingkan wanita. Pria diduga memiliki gaya hidup yang cenderung dapat meningkatkan tekanan darah dibanding wanita. Namun, setelah memasuki masa menopause, prevalensi hipertensi pada wanita meningkat.

Pada penelitian ini didapatkan $72 \%$ pasien hipertensi dengan IMT di atas normal. Mekanisme obesitas dapat meningkatkan tekanan darah masih terus dipelajari lebih lanjut secara intensif. Namun, dari beberapa penelitian yang telah dilakukan, didapatkan beberapa penyebab yang diduga sebagai faktor terjadinya peningkatan tekanan darah pada orang yang mengalami obesitas. Gangguan ginjal-tekanan natriuresis karena kompresi fisik ginjal dan aktivasi dari jalur RAAS dan SNS diduga sebagai penyebab peningkatan tekanan darah pada orang dengan obesitas. ${ }^{17}$

Pada penelitian ini didapatkan hubungan yang bermakna antara aktivitas fisik total dengan kontrol tekanan darah pada pasien hipertensi $(p=0,027)$. Secara umum, olahraga mengurangi tekanan darah dengan mekanisme resistensi vaskular sistemik, aktivitas simpatis, aktivitas renin plasma, penilaian model homeostasis, indeks resistensi insulin, berat badan, dan lingkar perut, dan memperbaiki profil lipid darah.

Di antara modifikasi gaya hidup dan diet yang direkomendasikan, satu yang direkomendasikan kepada semua orang dengan hipertensi, terlepas dari terapi farmakologis, adalah Dietary Approachesa to Stop Hypertension (DASH), diet yang menganjurkan konsumsi serat dan kalium melalui buah-buahan dan sayuran, penurunan konsumsi kadar lemak total dan jenuh dengan mengurangi konsumsi daging dan produk hewani, dan konsumi protein secara adekuat melalui daging tanpa lemak dan produk susu rendah lemak, sebagai alternatif dari makanan yang tinggi lemak atau daging olahan. ${ }^{23}$ Diet ini telah terbukti efektif dalam mengelola tekanan darah, dengan uji coba DASH awal menunjukkan penurunan tekanan darah sistolik $11,4 \mathrm{mmHg}$ dan penurunan tekanan darah diastolik $5,5 \mathrm{mmHg}$ dibandingkan dengan subjek kontrol. .24

Pola makan yang tinggi akan buah dan sayuran, seperti diet vegetarian dan diet mediterania, telah menunjukkan keefektifan dalam mengontrol tekanan darah. ${ }^{27}$ Mekanisme tentang bagaimana buah-buahan dan sayuran dapat membantu menurunkan tekanan darah melalui kandungan kalium, flavonoid, polifenol, dan kandungan serat di dalamnya. Kadar kalium serum telah terbukti menunjukkan hubungan berbanding terbalik dengan tekanan darah, dengan intervensi diet antihipertensi yang mendorong untuk mengurangi konsumsi natrium dan meningkatkan konsumsi kalium untuk meningkatkan rasio natrium-kalium dalam makanan yang akhirnya dapat menurunkan tekanan darah. ${ }^{28-30}$ Penelitian ini menemukan bahwa tidak terdapat hubungan yang bermakna secara statistik antara pola makan dengan tekanan darah pada pasien hipertensi $(p=1,000)$. Hal ini mungkin disebabkan oleh karakteristik subjek penelitian seperti sebagian besar IMT di atas normal, tingkat pendidikan yang rendah sehingga mempengaruhi kemampuan subjek untuk mengingat kembali makanan yang telah dikonsumsi. 
Tidak adanya rincian dan porsi makanan yang dikonsumsi oleh subjek penelitian dimungkinkan menjadi salah satu faktor hasil penelitian yang demikian.

Saran untuk peneliti selanjutnya diharapkan bisa memperluas daerah cakupan penelitian, tidak hanya dua kecamatan di Kabupaten Kapuas Hulu, melainkan seluruh kecamatan sehingga diharapkan menghasilkan data penelitian yang cukup banyak dan bervariasi.

\section{Kesimpulan}

Berdasarkan hasil penelitian ini, diperoleh kesimpulan bahwa aktivitas fisik memiliki hubungan yang bermakna dengan kontrol tekanan darah.

\section{Daftar Pustaka}

1. Kementerian Kesehatan Republik Indonesia. Hipertensi. Jakarta: Pusat Data dan Informasi Kementrian Kesehatan RI. 2014.

2. Williams B, Mancia G, Spiering W, Rosei EA, Azizi M, Burnier M, et al. 2018 ESC/ ESH Guidlines for the Management of Arterial Hypertension. Eur Heart J. 2018; 39: 3021-104.

3. WHO. Hypertension. [Internet]. https:// www.who.int/news-room/fact-sheets/ detail/hypertension. Diakses 11 Desember 2019.

4. Kementerian Kesehatan Republik Indonesia. Hasil Utama Riskesdas 2013. Jakarta: Kementerian Kesehatan RI Badan Penelitian dan Pengembangan Kesehatan. 2013.

5. Kementerian Kesehatan Republik Indonesia. Hasil Utama Riskesdas 2018. Jakarta: Kementerian Kesehatan RI Badan Penelitian dan Pengembangan Kesehatan. 2018.

6. Lilly LS (Editor). Pathophysiology of Heart Disease. Philadelphia: Wolters Kluwers. 2018.
7. Popkin BM, Adair LS, Ng SW. Global Nutrition Transition and the Pandemic of Obesity in Developing Countries. Nutr Rev. 2012; 70: 3-21. Kotchen TA. The Search for Strategies to Control Hypertension. Circulation. 2010; 12(2):1141-3.

8. Cheng S, Yu H, Chen Y, Chen C, Lien W, Yang P, Hu G. Physical Activity and Risk of Cardiovascular Disease Among Older Adults. Int J Gerontol. 2013; 7(3):133-6.

9. Kaplan NM, Victor RG, Flynn JT. Kaplan's Clinical Hypertension. 10 $0^{\text {th }}$ Edition. Lippincott Williams \& Wilkins. 2010.

10. Tseng C, Yen AM, Chiu SY, Chen L, Chen HA. Predictive Model for Risk of Prehypertension and Hypertension and Expected Benefit After Population-Based Life-Style Modification (KCIS No.24). Am J Hypertens. 2012; 25(2):171-9.

11. Romauli. Pengaruh Gaya Hidup terhadap Kejadian Hipertensi Di RSUD Dr. H. Kumpulan Pane Tebing Tinggi Medan Tahun 2014. [Thesis]. Repository Institusi Universitas Sumatera Utara. 2015.

12. Saxon S, Etten M, Perkins E. The Nervous System. In: A Guide for the Helping Professions: Physical Change \& Aging. New York: Springer. 2010.

13. Rolfes SR, Pinna K, Whitney E. Understanding Normal and Clinical Nutrition. Stamford USA: Cengage Learning. 2014

14. Frayar $C D$, Ostchega $Y$, Hales $C M$, Zhang G, Kruszon-Moran D. Hypertension Prevalence and Control Among Adults: United States, 2015-2016. 2017; 289: 1-8.

15. Choi HM, Kim HC, Kang DR. Sex Differences in Hypertension Prevalence and Control: Analysis of the 2010-2014 Korea National Health and Nutrition Examination Survey. PLOS One. 2017; 12(5):1-13.

16. Hall JE, Carmo JM, Da Silva AA, Wang Z, Hall ME. Obesity - Induced Hypertension Interaction of Neurohumoral and Renal Mechanism. AHA journals. 2015; 116:9911006. 
18. Diaz KM, Shimbo D. Physical Activity and the Prevention of Hypertension. Curr Hypertens Rep. 2013;15:659-68.

19. Cornelissen VA, Smart NA. Exercise Training for Blood Pressure: A Systematic Review and Meta-Analysis. J Am Heart Assoc. 2013; 2:e004473.

20. Pescatello LS, Franklin BA, Fagard R, Farquhar WB, Kelley GA, Ray CA. Exercise and Hypertension. Med Sci Sports Exerc. 2004; 36:533-53.

21. Pescatello LS. Exercise and Hypertension: Recent Advances in Exercise Prescription. Curr Hypertens Rep. 2005; 7:281-6.

22. Huai $P$, Xun H, Reilly KH, Wang Y, Ma W, $X i B$. Physical Activity and Risk of Hypertension A Meta-Analysis of Prospective Cohort Studies. AHA journals. 2013; 62:1021-6.

23. Tyson CC, Nwankwo C, Lin PH, Svetkey LP. The Dietary Approaches to Stop Hypertension (DASH) Eating Pattern in Special Populations. Curr Hypertens Rep. 2012; 14:388-96.

24. Kwan MW, Wong MC, Wang HH, Liu KQ, Lee CL, Yan BP, Yu CM, Griffiths SM. Compliance with the Dietary Approaches to Stop Hypertension (DASH) Diet: A Systematic Review. PLOS One. 2013;8:e78412.
25. He W, Zhang M, Zhao M, Davis LS, Blackwell TS, Yull F, Breyer MD, Hao CM. Increased Dietary Sodium Induced COX2 Expression by Activiting NFkB in Renal Medullary Interstitial Cells. Pflugers Arch. 2014 Feb; 466(2):357-67.

26. Sacks FM, Svetkey LP, Vollmer WM, Appel LJ, Bray GA, Harsha D, Obarzanek E, Conlin PR, Miller ER 3rd, SimonsMorton DG, Karanja N, Lin PH. DASHSodium Collaborative Research Group. N Engl J Med. 2001; 344(1): 3-10.

27. Drouin-Chartier JP, Gigleux I, Tremblay AJ, Poirier L, Lamarche B, Couture P. Impact of Diary Consumption on Essential Hypertension: A Clinical Study. Nutr J. 2014; $13: 83$.

28. Aaron KJ, Sanders PW. Role of Dietary Salt and Potassium Intake in Cardiovascular Health and Disease: A Review of The Evidence. Mayo Clin Proc. 2013; 88: 987-95.

29. Perez V, Chang ET. Sodium-to-Potassium Ratio and Blood Pressure, Hypertension, and Related Factors. Adv Nutr. 2014; 5:712-41.

30. Kanbay M, Bayram Y, Solak Y, Sanders PW. Dietary Potassium: A Key Mediator of The Cardiovascular Response to Dietary Sodium Chloride. J Am Soc Hypertens. 2013; 7: 395-400. 